\title{
Green meetings: ecocertification of sustainable events in conference and business tourism
}

\author{
L. Ranacher \& U. Pröbstl-Haider \\ Department for Landscape, Recreation and Conservation Planning, \\ University of Applied Life Sciences Vienna, Austria
}

\begin{abstract}
Conference and business tourism is increasing in economic importance, and negative environmental impacts of associated events can be significant. One method of making such events more sustainable is the ecocertification of green meetings. Ecocertification is a common tool for the advancement of sustainability in the tourism industry, and some empirical research has already been dedicated to the perception of ecolabels, as well as to incentives for and inhibitors against joining ecocertification schemes. For the special segment of green meetings, however, such research is pending. This study, therefore, is dedicated to the perception of ecocertified green meetings and to the certification process involved. Qualitative and quantitative research methods are employed to investigate the perception of the congress facility manager, an event manager and the attendees of an ecocertified conference at the Congress Centre Alpbach in Tyrol, Austria. The congress facility manager and the event manager are interviewed via expert interviews. For the conference attendees, a standardised questionnaire is used. The results reveal the level of awareness concerning the existence of the Austrian Green Meetings Certificate and the perception of an ecocertified green meeting including its associated benefits. Furthermore, the perception of the certification process itself, the event manager's reasons for pursuing certification, the congress facility's role in the certification process, as well as limitations to encouraging environmentally friendly travel are reported. The paper is concluded with a discussion of preconditions and requirements necessary to increase the number of green meetings in Austria.

Keywords: Green meetings, ecocertification, sustainable event, sustainable tourism.
\end{abstract}




\section{Introduction}

Conference and business tourism is an emerging industry, encompassing events, conferences, meetings, conventions, fairs and exhibitions. Their negative environmental impacts are becoming increasingly known and attention is being paid to foster better environmental management strategies [1]. In the meetings industry, the term 'green meetings' is used for events in conference and business tourism that minimise environmental impacts using a triple bottom line approach [2].

Hosting a green meeting is accompanied by benefits such as image improvement, reduced costs and the raising of awareness for environmental issues [3]. Furthermore, sustainable event management can result in a competitive advantage, as it can be used as a differentiating tool to distinguish the event from those of conventional non-green meetings [4]. On the other hand, green meetings are said to be time consuming, difficult to organise and can even lead to an increase in costs. Additionally, lack of information and a certain sustainability-weariness are often considered inhibitors [5], and even scientists remain sceptical of attempts to make conferences sustainable [6].

It can be agreed upon that actions to make events more sustainable are laudable. However, the question arises of how to support the proliferation of green meetings in conference and business tourism? Scholars argue that more research in the area of green events is required to identify success factors as well as barriers for their implementation [7].

Ecocertification for green meetings is one way to go: It is a popular tool to promote sustainability in tourism, and describes a procedure that audits tourism facilities or services and gives written assurance that they meet specific standards and are thus awarded a marketable logo [8]. Such certification schemes are increasingly available for events too: International standards such as BS 8901, ISO 20121, and other green meeting guidelines are currently considered to be leading [9].

Ecocertification aims to influence tourists to purchase greener holidays and hotel managers to implement environmental measures [10]. Thereby they create a balance between maintaining profitability and reducing environmental impact [11]. Ecocertification helps establish trust, as greenwashing - the unjustified advertising and marketing of products or policies as environmentally friendly to gain an economic advantage - is a common problem [12]. The availability of ecocertification for green meetings is therefore considered to promote sustainability in the meetings industry by generating benefits for the event manager whilst minimising environmental impacts and avoiding reproaches of greenwashing.

For every ecocertification to function properly, consumers need to have confidence in the credibility of ecolabels, and producers need to believe that obtaining an ecolabel will benefit their sales $[13,14]$. Empirical research reveals controversial results about the effectiveness of ecocertification for promoting sustainable tourism: There are more than 60 ecolabels in Europe [15] and, owing to the number and variety of available certification schemes, tourists have 
difficulties identifying which certifications are trustworthy. They differ in intention, criteria, geographical scope, send confusing messages and are often of low quality [16]. As a result, confusion, negative attitudes, and ignorance among tourists have been reported $[17,18]$.

Environmental responsibility is a strong motivator for implementing environmental measures and for pursuing ecocertification [19]. Nevertheless, ecocertification also serves as a key to the green market. Thus, the proliferation of ecolabels is not only the result of hoteliers' increasing environmental awareness, but also of them addressing different market segments [20]. Barriers against ecocertification of tourism facilities are high certification costs, the fear of jeopardising consumer satisfaction, lack of time, knowledge and environmental awareness, as well as difficulties to involve staff [18].

In Austria, the 'Austrian Ecolabel for Tourism' was launched in 1996 as the first official nation-wide certification system for tourism in Europe, and it soon became one of the most sophisticated ecolabels in Europe [21]. Since 2010, an adapted version - the 'Austrian Green Meetings Certificate' - is available for congresses, company meetings, trade fairs and seminars [22]. For Austria, being a popular destination for congresses and similar events, this step towards green meetings is promising.

In order to investigate how ecocertification contributes to the proliferation of green meetings in Austria, it is crucial to understand how an ecocertified green meeting and the certification process is perceived by its attendees, event manager and the hosting facility.

\section{Methodological approach}

\subsection{Selection of case study}

The Congress Centre Alpbach in Tyrol, Austria is located in a popular tourist destination. The congress facility is Green Globe certified and a licensee of the Austrian Green Meetings Certificate. One of the many events hosted at the Congress Centre Alpbach in 2012 was the ' 1 st International Conference on Forests for People', which received the Austrian Green Meetings Certificate.

The proliferation of ecocertified green meetings is considered to be dependent on event managers' perception of the certification process, as they are the ones deciding on whether to pursue ecocertification for a meeting or not. Furthermore, the congress facility is considered to play a decisive role in the certification process, as they are the licensees who host the conference and handle the certification process. Last but not least, the perception of the conference attendees is important to identify whether environmental measures are noticed and how they are evaluated. Acknowledging the importance of these three stakeholders, the following aspects will be covered:

- What is the level of awareness concerning the Austrian Green Meetings Certificate?

- In which ways is a green meeting beneficial for event managers?

- How is a certified green meeting perceived by the attendees? 
- How is the certification process perceived?

- Who sets the impulse for ecocertification?

\subsection{Interviews with the event manager and the facility manager}

Expert interviews were conducted with the hotel manager and event organiser to gain insight into their perception of the ecocertification process. The interviews were conducted face-to-face and via telephone, using a guideline specified to the expert's role in the ecocertification process. The interviews were transcribed and analysed using extraction to structure them around the key research themes.

\subsection{Questionnaire for the conference attendees}

The conference attendees were handed out a standardised questionnaire, asking whether they were aware that the conference was certified, whether they had noticed the environmental efforts and how they had travelled to the conference. The data was coded and analysed with SPSS using relative frequencies and chisquare tests.

\section{Main findings}

\subsection{Interview with the event manager}

\subsubsection{Perception of the Austrian Green Meetings Certificate}

The event manager knew the Austrian Ecolabel for Tourism and about green meetings, but the availability of a national label was considered a novelty. Despite the fact that a trend for sustainable conferences and international green meeting initiatives was identified, green meetings were considered to present a niche market:

"I think there is a specific clientele or target group who knows about green meetings. Especially people coming from natural sciences or social sciences, who do research on sustainability."

The availability of the Austrian Green Meetings Certificate was considered a positive development in the Austrian meetings industry, but the demand for ecocertification was estimated to be only limited, as sustainability in event management only plays a minor role for the majority of event managers.

\subsubsection{Perception of the environmental efforts}

Environmental efforts were considered to contribute to the overall quality and sustainability of the conference. Especially the efforts concerning catering (i.e. local and organic foods) were very positively perceived, as they contributed to the whole atmosphere of the conference.

The reduction of plastic waste, promotional gifts and paper, as well as the efficient use of renewable energy in the conference facility were acknowledged. Field trips were conducted via shuttle bus and accommodation was in walking distance from the congress facility, to reduce emissions. However, concerning 
travel to the congress facility, the environmental benefits were considered to be limited:

"Alpbach is located remotely in the Alps and therefore difficult to reach with public transportation. Through offering a shuttle service from Munich airport to Alpbach we were able to reduce emissions. But I think, in terms of environmentally friendly travel, there is still room for improvement."

The event manager was aware that international conferences are important for the scientific community to engage in networking and therefore will always depend on people travelling by plane.

\subsubsection{The role of event manager in the certification process}

It was important for the event manager to support the green image of her research facility, and the conference was planned from the beginning to be as green as possible. The conference had to be consistent with the university's profile. Apart from image reasons, the support and personal commitment of employees also provided a significant incentive for hosting a green meeting:

"This is what we want and that is also the attitude of our employees. Because in everyday life we are always dealing with topics such as Fair Trade, local products and waste separation - of course we organise a green meeting."

The green meeting was also intended to create awareness for the issue of sustainability, so that every single conference attendee would become aware of her or his environmental impacts. In total, image reasons and personal moral responsibility were the main reasons for hosting a green meeting.

\subsubsection{The event manager's perception of the certification process}

Despite the event manager's intention to host a green meeting, the actual impulse to ecocertify the conference came from the congress facility. The event manager was informed about ecocertification and was offered expertise in the form of a green meetings manager. It was considered a great advantage that the congress facility already fulfilled many criteria required for certification, and the facility was considered to significantly contribute to the general feasibility of the certification process. Concerning ecocertification itself, the flexibility of criteria - some are obligatory others can be chosen from a given set of criteria - was considered to ease the ecocertification process. No major obstacles or difficulties were identified, but the event manager was aware that cost limitations or some criteria could present an obstacle:

"Scientific conferences, especially, are very budget oriented, and the question automatically arises wether additional expenses for certification can be allowed. If the cost would have increased significantly, we could not have done it. Also, if we had had to fulfil all criteria, it would not have been possible."

Overall, the ecocertification process was perceived as requiring some extra effort, but as being definitely feasible due to the flexibility of criteria, the facility's assistance during the whole ecocertification process and because the facility already fulfilled some of the required criteria. 


\subsection{Interview with the facility manager}

\subsubsection{Benefits associated with the Austrian Green Meetings Certificate}

When the congress facility started to offer green meetings, they soon realised that an external verification of environmental claims would be necessary, because customers increasingly asked for it. The Austrian Green Meetings Certificate was chosen for this purpose, because it is a well-known certificate and certifies both the facility and the hosted events. This is of central importance because, within Austria, the certificate is considered to have the status of a brand:

"Ecocertified green meetings can be used for marketing purposes, public relations or corporate social responsibility reporting. The certificate allows events to differentiate themselves from others, and to position themselves on the green market to gain competitive advantages."

Although it is considered to be of limited international relevance, it is still seen as a useful tool to raise awareness for environmental issues, as nearly half of all visitors attended a green meeting at Alpbach and take this idea home.

\subsubsection{Perception of the environmental efforts}

Feedback on ecocertified green meetings was reported to be overwhelmingly positive. Environmental efforts are differently perceived and therefore have to be communicated in various ways. For example, concerning renewable energy supply and energy saving devices, active information through a tour upon attendees' arrival is necessary. On the other hand, green meeting attendees were found to be very sensitive towards environmental efforts surrounding food. Food is labelled (e.g. as organic) and noticed immediately. Concerning environmentally friendly travel, the facility manager is aware that international attendees will always remain part of this business:

"We cannot exclude attendees who have to travel by plane to get to Alpbach, or ask them to travel by ship instead. But we try to optimise environmental measures where it is feasible to do so."

Attendees are actively informed about environmentally friendly travel and the possibility to travel with public transportation, and carbon offsetting is encouraged.

\subsubsection{The role of the congress facility in the certification process}

The Congress Centre Alpbach is usually chosen because of its complete offer as an international congress facility. The integration of green meetings in their offers and the possibility to ecocertify meetings are considered cherries on the icing:

"Ecocertified green meetings are largely the result of our initiative. Event managers choose Alpbach because of its complete offer. To win them over for ecocertification, we need to actively inform them and ease their fears of escalating bureaucracy and costs."

Through the facility's active role, by providing information and offering expertise, they make ecocertification palatable for event managers. Event managers are informed about the possibility of ecocertification and are 
encouraged by the provision of expertise and precise information on the expected workload and the obtained benefits.

\subsubsection{The facility manager's perception of the certification process}

Event managers are often afraid of increased costs and workload linked to ecocertification. According to the facility manager, these fears are unfounded:

"Because we have already implemented many criteria in our congress facility, ecocertification for green meetings is proffered on a silver platter. Of course the event manger has to ensure compliance with the criteria, which is associated with some extra effort. But this is just a question of willingness, as the certification was designed to be attractive for event managers, and not to scare them off."

A cost increase is often considered a barrier for certification, but in comparison to the overall costs of a conference, these additional expenses are minimal and contribute directly to the quality of the event. For example, catering according to certification criteria is more expensive, but is composed of high quality products.

The flexibility of certification criteria and the handling of the ecocertification process by the congress facility were considered advantages. The facility manager identified no significant obstacles needing to be faced in the ecocertification process. The decision for or against ecocertification was not considered to be a question of available resources, but rather a question of willingness.

\subsection{Questionnaires for the conference attendees}

\subsubsection{Attendees' awareness of the Austrian Green Meetings Certificate}

In total, 79 questionnaires were received, constituting a $50 \%$ return rate. $51 \%$ of the conference attendees came from Europe, and 18\% from Austria. International attendees from other continents made up nearly one third. Figure 1 illustrates that

Did you know prior to your arrival that the conference was ecocertified?
Have you heard about the Austrian Green Meetings Certificate?

$$
\text { yes } \quad \text { no }
$$
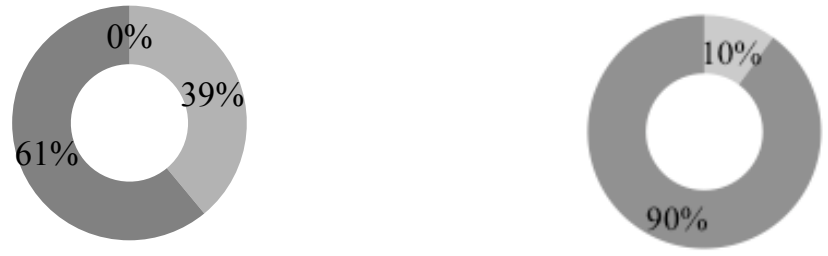

Figure 1: How many attendees knew about the ecocertification? 
$39 \%$ of the attendees knew prior to their arrival that the conference was ecocertified, and that $10 \%$ had heard of the certificate before. According to comments made on the questionnaire, attendees knew about the ecocertification via e-mail, the conference homepage and the conference outline.

\subsubsection{Attendees' perception of the environmental efforts}

The environmental efforts of the conference were noticed by the majority of attendees and evaluated as positive $(99 \%)$ and contributing to the quality of the conference $(87 \%)$. However, they were noticed to a different degree, as illustrated in figure 2 .

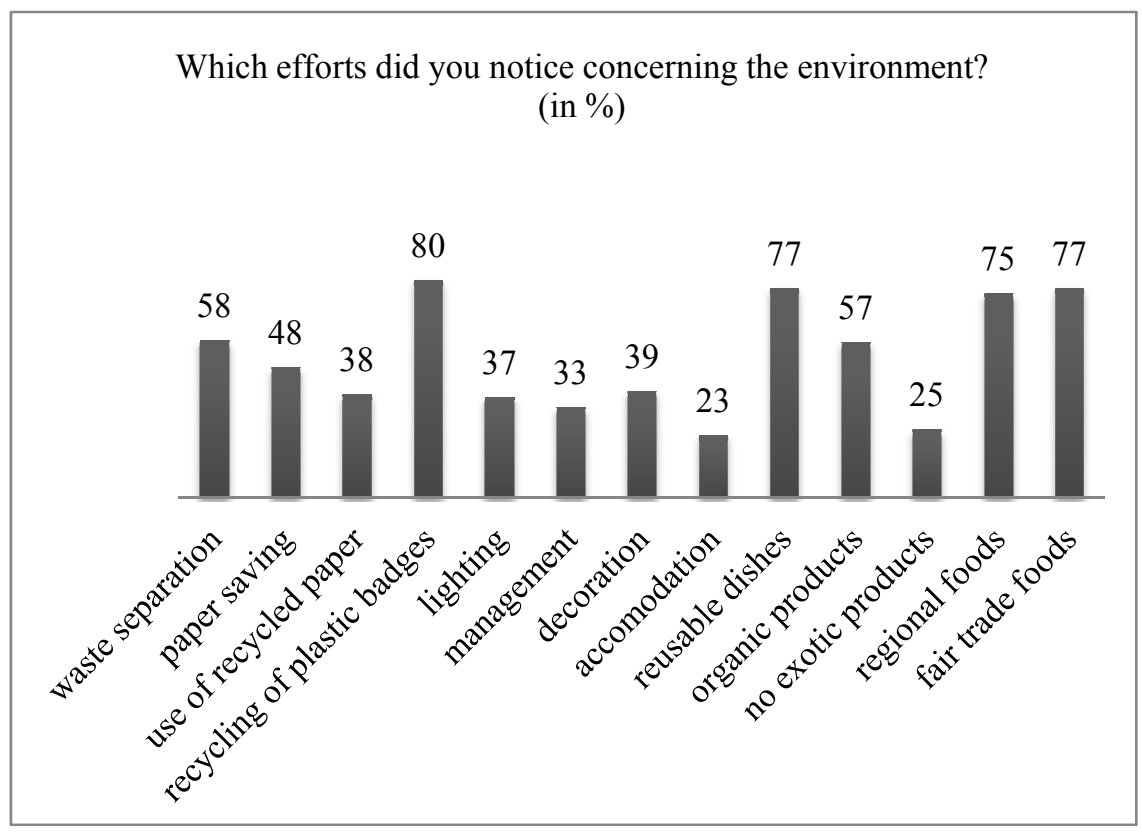

Figure 2: Which efforts were noticed?

Efforts concerning the plastic badges (80\%), dishes (77\%), fair trade (77\%) and local products $(75 \%)$ were noticed most, whereas no exotic produce $(25 \%)$ and accommodation (23\%) scored lowest.

Comments made on the questionnaire revealed scepticism about the 'greenness' of the conference due to its remote location. Furthermore, the availability of bananas, which obviously did not fit in with the claimed effort 'no exotic produce,' explains its low score and was negatively commented on. This reveals that attendees are very sensitive towards green claims made.

\subsubsection{Travel choice and evaluation of environmentally friendly alternatives}

Attendees mainly travelled to the conference via train or bus (48\%) and plane $(47 \%)$. In total, one third came to the conference by car, travelling either with their own car (13\%) or as a passenger in a car $(20 \%)$, as illustrated in figure 3 . 
The high use of public transport is explained by attendees who used both plane and public transport and therefore made double entries.

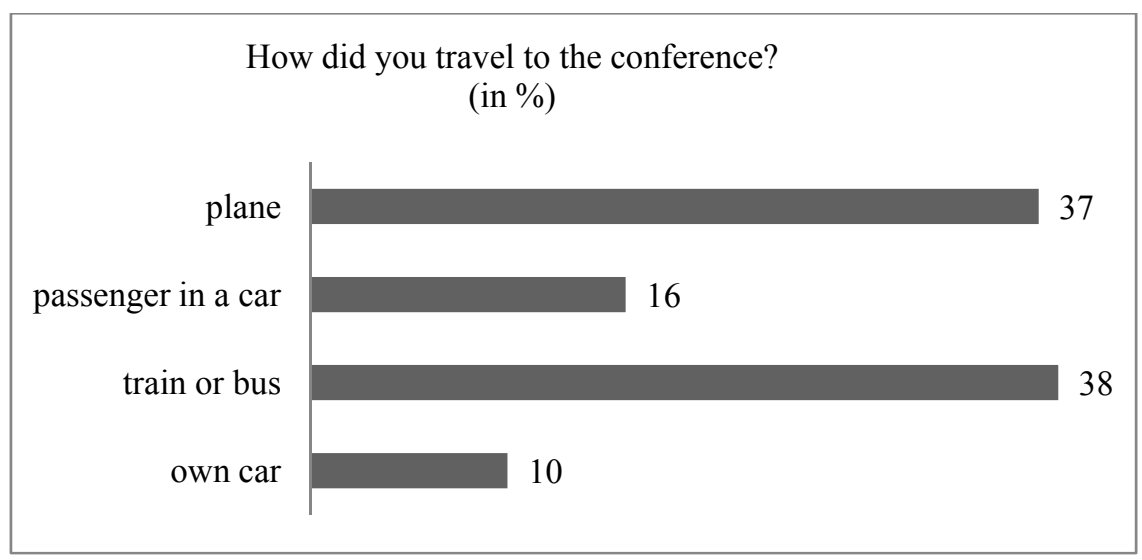

Figure 3: How did the conference attendees travel to Alpbach?

The majority of attendees who travelled with public transport were either very satisfied $(41 \%)$ or satisfied $(41 \%)$ with the service. However, comments on the questionnaires revealed that there had been some difficulties understanding the schedule and travel options to the conference.

\section{Conclusion}

Ecocertification for green meetings is considered a promising tool to reduce environmental impacts of events associated with conference and business tourism. In order to investigate how ecocertification can contribute to the proliferation of green meetings in Austria, it is essential to understand the feasibility of the ecocertification process and the perception of green meetings.

Awareness: The Austrian Ecolabel for Tourism is a well-established brand. Its adapted version - the Austrian Green Meetings Certificate - is considered to profit from that popularity. Nevertheless, awareness of the availability of this certification among event stakeholders is low. This can be explained by the international background of the conference attendees, the ecolabel's recent establishment, and its application in a specific niche market tourism segment, supporting research on the general low awareness of ecolabels in tourism [23].

Perception: The majority of attendees perceive an ecocertified green meeting overwhelmingly as positive and as a contribution to the quality of the conference. Green elements concerning catering raised more attention than those concerning waste management and energy efficiency, and are useful vectors for transporting environmental awareness. However, some attendees were sceptical about the green claims made. This is considered to be linked to the attendees' expanded knowledge of sustainability issues, just as environmentally aware consumers have been found to be the most sceptic [24]. 
Benefits: An ecocertified green meeting is considered to be beneficial for the event manager's organisation or company, as it can be used for image and marketing purposes. Moreover, the certificate's function as an external verification for environmental claims is appreciated. This supports the argument that, even though there are numerous studies of tourists' scepticism of ecocertification, it is still the most preferred attribute, and reflects the need for external verification of environmental claims in the tourism industry [25].

Reasons to ecocertification The ecocertification of green meetings is perceived as a cherry on the icing, suggesting that other considerations than the availability of ecocertification and its attributed benefits are important when choosing a congress facility. The proliferation of green meetings is considered to be dependent on event managers' sense of environmental responsibility. As this is influenced by personal, sociocultural and situational factors [26], there are many different factors explaining why event managers choose to ecolabel their meetings, and future research should be dedicated to these factors.

Barriers: The main barrier against the ecocertification of green meetings is their perceived resource intensity. Event managers are afraid of escalating costs and workload associated with the certification process. An ecocertified green meeting at the researched facility was found to involve only a small increase of costs and workload, in comparison to the overall effort required to organise a conference. No significant barrier for the ecocertification of green meetings was identified, but rather a lack of event managers' willingness was made out. Nevertheless, budget restrictions and some criteria can present an obstacle.

Impulse: A push from the congress facility to encourage the ecocertification of green meetings was needed. The facility informs event managers about the environmental impacts associated with their planned event, the required resources, as well as the benefits they will derive from certification, and provides assistance throughout the certification process. Thus, the facility is considered to play a vital role in the decision process for or against pursuing certification. This suggests that, if congress facilities provide in-depth information about environmental impacts and assist event managers in the organisation, they have the ability to encourage ecocertification for green meetings.

Travel: Incentivising environmentally friendly travel to the congress facility remains a challenge. Potential lies in encouraging the use of public transport or car sharing possibilities. Both facility manager and event manager accept that there is a divergence between their sense of environmental responsibility and business reality, and both focus on the areas that are economically viable and possible to implement.

The discussion shows that the Austrian Green Meetings Certificate is an attractive ecolabel for event managers. Gaining ecocertification is considered to come down to a question of willingness, provided the congress facility supports event managers throughout the whole process. This successful example from Austria shows that ecocertification for green meetings can be a feasible and attractive tool for the advancement of sustainability in the meetings industry.

Future research should investigate ecocertification for green meetings on a broader scope. For example, several ecocertified green meetings should be 
examined to gain insight into the experiences of various event managers, attendees, and managers of licensed congress facilities.

\section{References}

[1] Getz, D., Event tourism: Definition, evolution and research. Tourism Management, 29(3), pp. 403-428, 2008.

[2] CIC, www.conventionindustry.org/standardspractices/GreenMeetings.aspx

[3] Green Meeting Guide 2009 Roll out the Green Carpet for your Participants; United Nations Environment Programme, Online. www.unep.fr/scp/publications/details.asp?id=DTI/1141/PA

[4] Henderson, S., The development of competitive advantage through sustainable event management. World Wide Hospitality and Tourism, 3(3), pp. 245-257, 2011.

[5] Aase, S., A Guide to Greener Meetings. Journal of the American Dietetic Association, 109(5), pp. 800-803, 2009.

[6] Guterman, L., Seeing Green in Conference Season. Cell, 137(7), pp. 11691171, 2009.

[7] Laing, J., \& Frost, W., How green was my festival: Exploring challenges and opportunities associated with staging green events. International Journal of Hospitality Management, 29(2), pp. 261-267, 2010.

[8] Honey, M., \& Stewart, E., Introduction. Ecotourism \& Certification Setting Standards in Practice, ed. M., Honey, Island Press: Washington, pp. 33-71, 2002.

[9] Sustainable Event Standards - Summary; Green Meetings Industry Council, Online. www.gmicglobal.org/resourace/collection/2A2E3AF10514-4AC9-B540-77016F1DB197/GMIC_Sustainable_Event_Standards_ Summary.pdf

[10] Buckley, R., Tourism Ecolabels, Annals of Tourism Research, 29(1), pp. 183-208, 2002.

[11] Musgrave, J. \& Raj, R., Introduction to a Conceptual Framework for Sustainable Events (Chapter 1). Event Management and Sustainability, eds. J., Musgrave \& R., Raj, CABI Publishing: Oxfordshire, pp. 1-12, 2009.

[12] Marcus, A., Green Advertising and Marketing, Environmental Encyclopaedia, 4(1), pp. 789-790, 2005.

[13] Hale, M., Ecolabelling and cleaner production: principles, problems, education and training in relation to the adoption of environmentally sound production processes, Journal of Cleaner Production, 4(2), pp. 85-95.

[14] Toth, R., Exploring the Concepts underlying Certification, Ecotourism \& Certification Setting Standards in Practice, ed. Honey, M., Island Press: Washington, pp. 73-101, 2002.

[15] Sloan, P., Legrand, W., \& Chen, J.S., Sustainability in the hospitality industry. Principles of Sustainable Operations. Routledge: London, New York, 2011. 
[16] Font, X., Regulating the Green Message: the Players in Ecolabelling, Tourism Ecolabelling: Certification and Promotion of Sustainable Management, eds. Font, X., \& Buckley, R., CABI Publishing: Cambridge, pp. 1-17, 2001.

[17] Buckley, R., Tourism and the Environment, Annual Review of Environment and Resources, 36(1), pp. 183-208, 2011.

[18] Ayuso, S., Comparing Voluntary Policy Instruments for Sustainable Tourism: The Experience of the Spanish Hotel Sector, Journal of Sustainable Tourism, 15(2), pp. 144-159, 2007.

[19] Vernon, J., Eddex, S., Pinder, D., \& Curry, K., The 'greening' of tourism micro businesses: outcomes of focus group investigations in south east Cornwall, Business Strategy and the Environment, 12(1), pp. 49-69, 2003.

[20] Pröbstl, U., Müller, F., Hotel certification and its relevance for sustainable development: examples from the European Alps; Sustainable Tourism V, ed. Pineda, F.D. \& Brebbia, C.A., WIT Press: Southampton, pp. 3-15, 2012.

[21] Hamele, H., Ecolabels for Tourism in Europe: The European Ecolabel for Tourism?; Tourism Ecolabelling: Certification and Promotion of Sustainable Management, eds. Font, X., \& Buckley, R., CABI Publishing: Cambridge, pp. 175-189, 2001.

[22] Bundesministerium für Land- und Forstwirtschaft, Umwelt und Wasserwirtschaft; Green Meetings und Green Events Richtlinie UZ 62, Online. http://www.acb.at/greenmeeting/files/UZ62_R1.2a_Green Meetings_2010.pdf

[23] Millar, M., \& Baloglu, S., Hotel Guests' Preferences for Green Guest Room Attributes, Cornell Hospitality Quatery, 52(3), pp. 302-311, 2011.

[24] Virgil E., \& Burton, L., Green Marketing, Encyclopaedia of Small Business, 1(4), pp. 630-633, 2011.

[25] Tomescu A.M., Aspects of service quality and ecolabelling of Romanian lodging services, Annals of the University of Oradea: Economic Science, 1(1), pp. 693-699, 2011.

[26] Tzeschentke, N.A., Kirk, D., \& Lynch, P.A., Going green: Decisional factors in small hospitality operations, International Journal of Hospitality Management, 27(1), pp. 126-133, 2008. 